\title{
Level and Type of Social support among senior secondary school students of Kashmir Valley: An exploratory study
}

\author{
Aadil Mohd Akhoon (M.A Education) \\ School of Education, \\ Lovely Professional University, Phagwara Punjab.
}

\begin{abstract}
The study was conducted to find the level and type of Social support among senior secondary school studentsstudents of Kashmir valley. Social support is a kind of support which we are getting from our friends, family members, neighbours and society. In order to obtain accurate and relevant data descriptive survey method and stratified random sampling technique was used in the present study. The sample size of the study was 202 senior secondary school students from Baramulla district of Kashmir valley. In order to collect data Social support scale developed by Vishal Sood and Arti Anand (2015) The objective of the study was to analyze the level of Social support and to find the differences in Social support with respect to gender and type of school. Null hypothesis were framed in order to test the objectives. Statistical techniques like mean, percentage, standard deviation and t-test were used. The results of the study revealed that maximum of the senior secondary school students are having average level of family, teacher, peer and online support. There is no significant difference between male and female senior secondary school students in their family, teacher, online and in overall social support, but there is significant difference between male and female senior secondary school students in peer support. There is no significant difference between government and private senior secondary school students in their perceived family, teacher, peer and social support.
\end{abstract}

Keywords: Social support

\section{INTRODUCTION}

Social support can be defined as any kind of help that an individual receives from the society. It can come from various things such as family, friends, neighbours, co-workers. Social support plays an important role in our daily life. We are human beings and we need support from our family members, friends, neighbours, particularly when we are in trouble and are facing problems. Social support is a process of communication which results in enhancing handling strategies, high sense of worth all the way. People who have broad friendship circle are having higher confidence and greater satisfaction with their daily lives and it also plays an important role in functioning of the body, on the other hand people who have no or very less friend circle tends to be hesitant, lazy, introvert, and they do not care what is going in his outside world.

A strong social support leads to better coping understanding and also develop good interpersonal skills. Social anxiety is one of the major problems in students who are not well adjusted in the society. HelShe may not be able to complete group tasks or he/she may not feel comfortable while asking help in classroom. Generally slow learners often face more problems as compared to other students (Gurnurg, 2006).

Social support is an aspect that can help the individuals to cope up with the stressful situations (Nahid and Sarkis, 1994). Social support is an unstable relationship through the replacement of emotional and social assets to make people perceive being loved and to support good mental health (Cohen and Wills, 1985). Social support is a method through which an individual acquires an important ability from important members such as siblings, peers, and parents (Wills, 1997). Social support refers to a support that helps an individual to control the situation efficiently (Hunt, 1997).Social support refers to the process of communication in relationships that helps an individual in reducing stress and completes the given task (Gottleb, 2000).

Social support could come up with a range of sources, such as members in the family, friend circle, romantic relations, pets, society ties, and colleagues. We have generally two types of sources in social support i.e., natural support which is family and friends and another is formal source i.e. mental health specialists and society organizations. The social support is known to be an essential factor useful in a various coping strategies. Social support plays an important role in our daily life. In addition social support from friend circle gives a very good retort to matrimonial stress, because they were not as much worried. Early family support and social support has been identified as important variable to develop helpful parental relationships and also have benefits to students from college and university levels (Taylor, 1990).

Schaefer, Coyne, and Lazarus (1981) explained five types of social support. They are:

1. Emotional maintain: Emotional hold is the offering of empathy, concern, affection, care, faith, receiving, closeness, back-up, or caring.

2. Esteem support: Is statement that boosts an individual's self-esteem so that they can handle their problems effectively or perform a desirable job.

3. Network support: Network is communication that reminds people that they are not alone in whatever position they are facing. 
4. Information support: It is the condition of counsel, direction, suggestion, or helpful information to somebody. These kinds of knowledge have prospective to assist others in solving problems.

5. Tangible hold up: Tangible support is the condition of economic aid, material goods, and any kind of services, also called instrumental support.

Female offer extra social support to others and are extra busy in their social networks. Evidence has also supported the notion that female may be superior provider of social support. In addition to being more involved in the giving of support, female are also extra likely to seek out of social support to deal with stress.

Many researchers found that boy's behaviours are generally more unfriendly, with a lesser amount of consider to crash their coping may have upon others, and women are extra pro social-active with significance stress on how their coping affects public around them.

Adelman and Albrecht (1987) explained social support as spoken and nonverbal language in receivers and senders which minimizes uncertainty in relation to the position, oneself, others, or the connection to enlarge a view of individuals directed in one's own experiences.

According to Gottlieb (2000) defined the procedure of social support is contact which results in enhancing managing strategies, high self-esteem, and capability all the way through actual or alleged contacts of physical, psychological and social resources.

Heller (1779) conducted the research in which he suggested that person with high social support can cope up with the environmental stress skilfully. He also found that people with high social support are having low psychological stress; similarly people with low social support have high psychological stress. Zhang (2012) examined that students who have less acculturative stress, they have a better adjustment and also have very low level of depression. Moreover, when students experienced a high level of stress, study exposed that perceived social support functions as a moderator for the connection between acculturative stress and depression. Park et al. (2012) concluded that social support affects our Health positively; three moderating factors must be kept in view (1) Support approving norms, (2) Support requiring situations, (3) Support accepting personal style.

Erkan Isik (2013) conducted a study in which he found that that social support from family, friends and other neighbours positively and locus of control was harmfully connected with occupational outcome potential. Results also found that social support was the unique important predictor of occupational outcome expectation. Azita and Vali (2016) found that there is a direct relationship between social support and academic adjustment and also direct relationship was verified between practical support and social adaptation among different types of academic support.

\section{OBJECTIVES OF THE STUDY}

The objectives formulated for the present study were:-

1. To analyze the level and type of social support among senior secondary school students.

2. To find the differences in social support with respect to gender and type of school.

\section{HYPOTHESES}

In the light of forgoing objectives following null hypothesis were framed for the present study:-

1. There exists no significant difference in social support of male and female senior secondary school students.

2. There exists no significant difference in social support of government and private senior secondary school students.

\section{METHOD}

The present study is descriptive in nature so descriptive survey method was used. The sample consists of 202 senior secondary school students from government and private schools affiliated to state board of school education (BOSE). The investigator used stratified random sampling in order to collect data from different senior secondary schools. For data collection Social support scale developed by Mrs. Indira Dhull and Ms. Sangeeta Godara in (2015) was used. The social support scale consists of 40 items out of which 3 items were negative items. It has four parts namely family support, teacher support, friends support and online support, all the four parts consists of 10 items each. Family support is a kind of support which we are getting from our parents and siblings in order to solve certain problem of an individual. Teacher support also plays an important role in motivating the student. Apart from these, internet also plays an essential role as a source of social support.

\section{RESULTS AND ANALYSIS}

Analysis of data means studying the tabulated data in order to determine the inherent facts. It involves breaking up of complex factors into simpler parts and putting them in new arrangement for the purpose of interpretation.

The distribution of scores showing the levels of the levels of Social support among senior secondary school students is given in table 1 . 
Table 1: showing the levels of Family support among senior secondary school students

\begin{tabular}{|c|c|c|}
\hline Levels & Frequency & Percent \\
\hline High & 1 & .5 \\
Above average & 28 & 13.9 \\
Average & 149 & 73.8 \\
Below average & 22 & 10.9 \\
Low & 2 & 1.0 \\
Total & 202 & 100.0 \\
\hline
\end{tabular}

To study the level of Social support among senior secondary school students the investigator collected the information from six senior secondary school students from one district in Kashmir. Table shows the five levels of family support namely High, above average, average, below average, and low. It is clear from the table 3.8 that $0.5 \%$ of senior secondary students are having are having high family support, $13.9 \%$ of senior secondary students are having above average level of family support and $73.8 \%$ of senior secondary students are having average level of family support. Table further revealed that $10.9 \%$ of senior secondary students are having below average level of family support, and only $1.0 \%$ of senior secondary students are having low level of family support. So it can be interpreted that maximum of senior secondary students are getting average level of family support.

Table 2: showing the levels of Teacher support among senior secondary school students

\begin{tabular}{|c|c|c|}
\hline Levels & Frequency & Percent \\
\hline Extremely high & 2 & 1.0 \\
Above average & 6 & 3.0 \\
Average & 182 & 90.1 \\
Below average & 8 & 4.0 \\
Low & 4 & 2.0 \\
Total & 202 & 100.0 \\
\hline
\end{tabular}

Table shows the five levels of Teacher support namely Extremely High, above average, average, below average, and low. It is clear from the table 4.8 that $1.0 \%$ of senior secondary students are having are having high Teacher support, $3.0 \%$ of senior secondary students are having above average level of Teacher support and $90.1 \%$ of senior secondary students are having average level of Teacher support. Table 2 also revealed that $4.0 \%$ of senior secondary students are having below average level of Teacher support, and only $2.0 \%$ of senior secondary students are having low level of Teacher support. So it can be interpreted that maximum of senior secondary students are getting average level of Teacher support.

Table 3: showing the levels of peer support among senior secondary school students

\begin{tabular}{|c|c|c|}
\hline Levels & Frequency & Percent \\
\hline Extremely high & 1 & .5 \\
Above average & 19 & 9.4 \\
Average & 170 & 84.2 \\
Below average & 10 & 5.0 \\
Low & 2 & 1.0 \\
Total & 202 & 100.0 \\
\hline
\end{tabular}

Table shows the five levels of Peer support namely Extremely High, above average, average, below average, and low. It is clear from the table 4.0 that $.5 \%$ of senior secondary students are having are having high Peer support, 9.4. \% of senior secondary students are having above average level of Peer support and $84.2 \%$ of senior secondary students are having average level of Peer support, the Table also revealed that $5.0 \%$ of senior secondary students are having below average level of Peer support, and only $1.0 \%$ of senior secondary students are having low level of Peer support. So it can be interpreted that maximum of senior secondary students are getting average level of Peer support. 
Table 4: showing the levels of online support among senior secondary school students

\begin{tabular}{|c|c|c|}
\hline Levels & Frequency & Percent \\
\hline Above average & 3 & 1.5 \\
Average & 186 & 92.1 \\
Below average & 13 & 6.4 \\
Total & 202 & 100.0 \\
\hline
\end{tabular}

Table 4 shows the three levels of online support namely above average, average, and below average. It is clear from the Table that $1.5 \%$ of senior secondary school student's possess above average level of online support, $92.1 \%$ of senior secondary school students are having average level of online support and $6.4 \%$ of senior secondary school students are having below average level of online support. Table also revealed that none $(0 \%)$ of senior secondary students reported extremely high, high and extremely low online support. So it can be interpreted that maximum of senior secondary school students are getting average level of online support.

Table 5: showing the levels of Social support among senior secondary school students

\begin{tabular}{|c|c|c|}
\hline Levels & Frequency & Percent \\
\hline Above average & 18 & 8.9 \\
Average & 167 & 82.7 \\
Below average & 14 & 6.9 \\
Low & 2 & 1.0 \\
Extremely low & 1 & .5 \\
Total & 202 & 100.0 \\
\hline
\end{tabular}

Table 5 shows the five levels of social support namely above average, average, below average, below average, low, and extremely low. It is clear from the table 5 that $8.9 \%$ of senior secondary school students are having above average level of social support, $82.7 \%$ of senior secondary school students are having average level of social support and $6.9 \%$ of senior secondary school students are having below average level of social support. Table 5 further revealed that $1.0 \%$ of senior secondary school students are having low level of social support, $0.5 \%$ of senior secondary school students are getting extremely low level of social support. So it can be interpreted that maximum of senior secondary students are getting average level of social support.

The distribution of scores for male senior secondary school students on the variable Social support is given in table 6 .

Table 6: showing the levels and percentage of male senior secondary students in all dimensions of Social support

\begin{tabular}{|c|c|c|c|c|c|c|}
\hline LEVELS & $\begin{array}{c}\text { No of } \\
\text { Students }\end{array}$ & SSFS & SSTS & SSPS & SSOS & SST \\
\hline \multirow{2}{*}{$\begin{array}{c}\text { Extremely } \\
\text { High }\end{array}$} & $\mathbf{N}$ & 1 & 1 & 0 & 0 & 8 \\
\hline & $\%$ & 0.99 & 0.99 & 0 & 0 & 7.92 \\
\hline \multirow[t]{2}{*}{ High } & $\mathbf{N}$ & 2 & 1 & 0 & 0 & 0 \\
\hline & $\%$ & 1.98 & 0.99 & 0 & 0 & 0 \\
\hline \multirow{2}{*}{$\begin{array}{c}\text { Above } \\
\text { average }\end{array}$} & $\mathbf{N}$ & 10 & 2 & 6 & 1 & 0 \\
\hline & $\%$ & 9.90 & 1.98 & 5.94 & 0.99 & 0 \\
\hline \multirow[t]{2}{*}{ Average } & $\mathbf{N}$ & 73 & 90 & 85 & 94 & 82 \\
\hline & $\%$ & 72.27 & 89.10 & 84.15 & 93.06 & 81.18 \\
\hline \multirow{2}{*}{$\begin{array}{c}\text { Below } \\
\text { average }\end{array}$} & $\mathbf{N}$ & 13 & 5 & 8 & 6 & 9 \\
\hline & $\%$ & 12.85 & 4.95 & 7.92 & 5.94 & 8.9 \\
\hline \multirow[t]{2}{*}{ Low } & $\mathbf{N}$ & 2 & 2 & 2 & 0 & 2 \\
\hline & $\%$ & 1.98 & 1.98 & 1.98 & 0 & 1.98 \\
\hline \multirow{2}{*}{$\begin{array}{c}\text { Extremely } \\
\text { low }\end{array}$} & $\mathbf{N}$ & 0 & 0 & 0 & 0 & 0 \\
\hline & $\%$ & 0 & 0 & 0 & 0 & 0 \\
\hline
\end{tabular}

Table 6 shows percentage distribution of male senior secondary school students in seven decreasing levels of Social support namely extremely high, high, above average, average, below average, low and extremely low. For Family support results revealed that 
$0.99 \%$ of male senior secondary school students reported extremely high Family support, $1.98 \%$ of male senior secondary school students reported high level of Family support and $9.90 \%$ of male senior secondary school students reported above average level of Family support. Table 6 further revealed that $72.27 \%$ of male senior secondary school students reported average level of Family support, $12.85 \%$ of senior secondary school students reported below average level of Family support, and only $1.98 \%$ of male senior secondary school students reported low level of Family support.

In the same way in Teacher support $0.99 \%$ of male senior secondary school students reported extremely high Teacher support, $0.99 \%$ of male senior secondary school students reported high level of Teacher support, and $1.98 \%$ of male senior secondary school students reported above average level of Teacher support. Table 6 further revealed that $89.10 \%$ of male senior secondary school students reported average level of Teacher support, $4.95 \%$ of senior secondary school students reported below average level of Teacher support, and only $1.98 \%$ of male senior secondary school students reported low level of Teacher support.

In the same way in Peer support $5.94 \%$ of male senior secondary school students reported above average level of Peer support, $84.15 \%$ of male senior secondary school students reported average level of Peer support and $7.92 \%$ of male senior secondary school students reported below average level of social support. Table 6 further revealed that $1.98 \%$ of male senior secondary school students reported low level of Peer support.

In the same way in online support $0.99 \%$ of male senior secondary school students reported above average level of online support, $93.06 \%$ of male senior secondary school students reported average level of online support, and 5.94\% of male senior secondary school students reported below average level of online support. Table 6 further showed that none $(0 \%)$ of the male senior secondary school students reported extremely high, high and extremely low level of online support.

In the same way in Social support $7.92 \%$ of male senior secondary school students reported extremely high level of Social support, $81.18 \%$ of male senior secondary school students reported average level of Social support and $8.9 \%$ of male senior secondary school students reported below average level of social support. Table 6 also revealed that $1.98 \%$ of male senior secondary school students reported low level of Social support and none $(0 \%)$ of the male senior secondary school students reported high and extremely low level of Social support.

\begin{tabular}{|c|c|c|c|c|c|c|}
\hline LEVELS & $\begin{array}{c}\text { No of } \\
\text { Students }\end{array}$ & SSFS & SSTS & SSPS & SSOS & SST \\
\hline \multirow[t]{2}{*}{ Extremely High } & $\mathbf{N}$ & 0 & 1 & 1 & 0 & 0 \\
\hline & $\%$ & 0 & 0.99 & 0.99 & 0 & 0 \\
\hline \multirow[t]{2}{*}{ High } & $\mathbf{N}$ & 0 & 0 & 0 & 0 & 0 \\
\hline & $\%$ & 0 & 0 & 0 & 0 & 0 \\
\hline \multirow[t]{2}{*}{ Above Average } & $\mathbf{N}$ & 16 & 4 & 13 & 2 & 10 \\
\hline & $\%$ & 15.84 & 3.96 & 12.87 & 1.98 & 9.90 \\
\hline \multirow[t]{2}{*}{ Average } & $\mathbf{N}$ & 76 & 92 & 85 & 91 & 85 \\
\hline & $\%$ & 75.24 & 91.08 & 84.15 & 90.09 & 84.15 \\
\hline \multirow[t]{2}{*}{ Below Average } & $\mathbf{N}$ & 9 & 3 & 2 & 8 & 5 \\
\hline & $\%$ & 8.9 & 2.97 & 1.98 & 7.92 & 4.95 \\
\hline \multirow[t]{2}{*}{ Low } & $\mathbf{N}$ & 0 & 1 & 0 & 0 & 1 \\
\hline & $\%$ & 0 & 0.99 & 0 & 0 & 0.99 \\
\hline \multirow[t]{2}{*}{ Extremely Low } & $\mathbf{N}$ & 0 & 0 & 0 & 0 & 0 \\
\hline & $\%$ & 0 & 0 & 0 & 0 & 0 \\
\hline
\end{tabular}

Table 7 shows percentage distribution of female senior secondary school students in seven decreasing levels of Social support namely extremely high, high, above average, average, below average, low and extremely low. For friend support results revealed that $15.84 \%$ of female senior secondary school students reported above average level of Family support, $75.24 \%$ of female senior secondary school students reported average level of Family support, and only $8.9 \%$ of female senior secondary school students reported below average level of Family support. Table also revealed that none $(0 \%)$ of the female senior secondary school students reported extremely high, high, low, and extremely low level of Family support.

In the same way in teacher support $0.99 \%$ of female senior secondary school students reported extremely high level of teacher support, $3.96 \%$ of female senior secondary school students reported above average level of teacher support and $91.08 \%$ of female senior secondary school students reported average level of teacher support. Table 7 further revealed that $2.97 \%$ of female senior secondary school students reported below average level of teacher support, and only $0.99 \%$ of female senior secondary school students showed low level of teacher support. 
In the same way in peer support $0.99 \%$ of female senior secondary school students reported extremely high level of peer support, $12.87 \%$ of female senior secondary school students reported above average level of peer support and $84.15 \%$ of female senior secondary school students reported average level of peer support. Table 7 further revealed that $1.98 \%$ of female senior secondary school students showed below average level of peer support and none of the $(0 \%)$ of female senior secondary school students reported below average, low and extremely low level of peer support.

In the same way in online support $1.98 \%$ of female senior secondary school students reported above average level of peer support, $90.09 \%$ of female senior secondary school students reported average level of peer support and $7.92 \%$ of female senior secondary school students reported below average level of social support. Table 7 also revealed that none (0\%) of senior secondary school students reported extremely, high, low and extremely low level of peer support.

Likewise in Social support $9.90 \%$ of female senior secondary school students reported above average level of Social support, $84.15 \%$ of female senior secondary school students reported average level of Social support and $4.91 \%$ of female senior secondary school students reported below average level of Social support. Table 7 also revealed that $0.99 \%$ of female senior secondary school students showed low level of Social support and none $(0 \%)$ of the female senior secondary school students reported extremely high, high, and extremely low level of Social support.

Table 8: showing the levels and percentage of government senior secondary students in all the four dimensions of

\begin{tabular}{|c|c|c|c|c|c|c|}
\hline \multicolumn{7}{|c|}{ 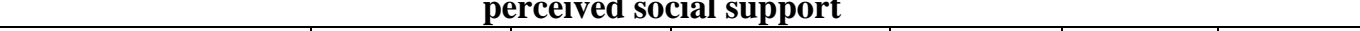 } \\
\hline LEVELS & $\begin{array}{c}\text { No oI } \\
\text { Students }\end{array}$ & 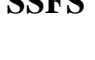 & SSIS & SSPS & SSOS & SST \\
\hline \multirow[t]{2}{*}{ Extremely High } & $\mathbf{N}$ & 0 & 80 & 5 & 0 & 0 \\
\hline & $\%$ & 0 & 79.20 & 4.95 & 0 & 0 \\
\hline \multirow[t]{2}{*}{ High } & $\mathbf{N}$ & 0 & 0 & 0 & 0 & 0 \\
\hline & $\%$ & 0 & 0 & 0 & 0 & 0 \\
\hline \multirow[t]{2}{*}{ Above Average } & $\mathbf{N}$ & 23 & 3 & 13 & 77 & 18 \\
\hline & $\%$ & 22.77 & 2.97 & 12.87 & 76.23 & 17.82 \\
\hline \multirow[t]{2}{*}{ Average } & $\mathbf{N}$ & 21 & 7 & 65 & 12 & 34 \\
\hline & $\%$ & 20.79 & 6.93 & 64.35 & 11.88 & 33.66 \\
\hline \multirow[t]{2}{*}{ Below Average } & $\mathbf{N}$ & 55 & 8 & 18 & 8 & 40 \\
\hline & $\%$ & 54.45 & 7.92 & 17.82 & 7.92 & 39.60 \\
\hline \multirow[t]{2}{*}{ Low } & $\mathbf{N}$ & 2 & 3 & 0 & 4 & 9 \\
\hline & $\%$ & 1.98 & 2.97 & 0 & 3.96 & 8.91 \\
\hline \multirow[t]{2}{*}{ Extremely low } & $\mathbf{N}$ & 0 & 0 & 0 & 0 & 0 \\
\hline & $\%$ & 0 & 0 & 0 & 0 & 0 \\
\hline
\end{tabular}

Table 8 shows percentage distribution of government senior secondary school students in seven decreasing levels of Family support namely extremely high, high, above average, average, below average, low and extremely low. For Family support results revealed that $22.77 \%$ of government senior secondary school students showed above average level of Family support, 20.79\% of government senior secondary school students reported average level of Family support, and only $54.45 \%$ of government senior secondary school students reported below average level of Family support and only 1.98\% of government senior secondary school students reported low level of Family support. Table 8 further revealed that none $(0 \%)$ of government senior secondary school student reported extremely high, high, and extremely low level of Family support.

In the same way in teacher support $79.20 \%$ of government senior secondary school students showed extremely high level of teacher support, $2.97 \%$ of government senior secondary school students showed above average level of teacher support and $6.93 \%$ of government senior secondary school students reported average level of teacher support. Table 8 also revealed that $7.92 \%$ of government senior secondary school students reported below average level of teacher support and $2.97 \%$ of government senior secondary school students reported low level of teacher support and none $(0 \%)$ government senior secondary school students reported extremely low level of teacher support.

In the same way in peer support $4.95 \%$ of government senior secondary school students showed extremely high level of online support, $12.87 \%$ of government senior secondary school students reported average level of peer support and $64.35 \%$ of government senior secondary school students reported average level peer support. Table 8 further showed 17.82\% of government senior secondary school students reported below average level of peer support and none $(0 \%)$ of government senior secondary school students reported high, low and extremely low level of peer support.

In the same way in online support $76.23 \%$ of government senior secondary school students showed above average level of online support, $11.88 \%$ of government senior secondary school students showed average level of online support and $7.92 \%$ of government 
senior secondary school students reported below average level of online support. Table 8 also showed that $3.96 \%$ of government senior secondary school students reported low level of online support and none (\%)\% of government senior secondary school students reported in extremely high, high and extremely low level of online support.

In the same way in social support $17.82 \%$ of government senior secondary school students showed above average level of social support, $33.66 \%$ of government senior secondary school students reported average level of social support, and $39.60 \%$ of government senior secondary school students reported below average level of social support. Table 8 also revealed that $8.91 \%$ of government senior secondary school students reported low level of social support and $(0 \%)$ of government senior secondary school students reported extremely high, high and extremely low level of social support.

Table 9: showing the levels and percentage of private senior secondary students in all the four dimensions of social

\begin{tabular}{|c|c|c|c|c|c|c|}
\hline \multicolumn{7}{|c|}{ support } \\
\hline LEVELS & $\begin{array}{c}\text { No. of } \\
\text { Students }\end{array}$ & SSFS & SSTS & SSPS & SSOS & SST \\
\hline \multirow[t]{2}{*}{ Extremely High } & $\mathbf{N}$ & 0 & 0 & 16 & 0 & 0 \\
\hline & $\%$ & 0 & 0 & 15.84 & 0 & 0 \\
\hline \multirow[t]{2}{*}{ High } & $\mathbf{N}$ & 0 & 0 & 0 & 0 & 0 \\
\hline & $\%$ & 0 & 0 & 0 & 0 & 0 \\
\hline \multirow[t]{2}{*}{ Above Average } & $\mathbf{N}$ & 12 & 9 & 8 & 1 & 7 \\
\hline & $\%$ & 11.88 & 8.91 & 7.92 & 0.99 & 6.93 \\
\hline \multirow[t]{2}{*}{ Average } & $\mathbf{N}$ & 62 & 84 & 75 & 90 & 84 \\
\hline & $\%$ & 61.38 & 83.16 & 74.25 & 89.10 & 83.16 \\
\hline \multirow[t]{2}{*}{ Below Average } & $\mathbf{N}$ & 15 & 4 & 0 & 10 & 10 \\
\hline & $\%$ & 14.85 & 3.96 & 0 & 9.90 & 9.90 \\
\hline \multirow[t]{2}{*}{ Low } & $\mathbf{N}$ & 12 & 4 & 2 & 0 & 0 \\
\hline & $\%$ & 11.88 & 3.96 & 1.98 & 0 & 0 \\
\hline \multirow[t]{2}{*}{ Extremely low } & $\mathbf{N}$ & 0 & 0 & 0 & 0 & 0 \\
\hline & $\%$ & 0 & 0 & 0 & 0 & 0 \\
\hline
\end{tabular}

Table 9 shows percentage distribution of female senior secondary school students in seven decreasing levels of Family support namely extremely high, high, above average, average, below average, low and extremely low. For family support results revealed that $11.88 \%$ of private senior secondary school students showed above average level of family support, $61.38 \%$ of private senior secondary school students reported average level of social support and $14.85 \%$ of private senior secondary school students reported below average level of social support the Table 1.9 further exposed that $10.89 \%$ of private senior secondary school students reported low level of family support and none $(0 \%)$ of the private senior secondary school students reported extremely high, high and extremely low level of family support.

In the same way in teacher support $8.91 \%$ of private senior secondary school students showed above average level of teacher support, $83.16 \%$ of private senior secondary school students reported average level of SSTS and 3.96\% of private senior secondary school students reported below average level of teacher support, the Table 9 also exposed that 3.96\% of private senior secondary school students reported low level of social support and none $(0 \%)$ reported extremely high, high and extremely low level of teacher support.

In the same way in peer support $15.84 \%$ of private senior secondary school students reported extremely high level of peer support, $7.92 \%$ of private senior secondary school students showed above average level of peer support and $74.25 \%$ of private senior secondary school students reported average level of peer support, the Table 9 also revealed that $1.98 \%$ of senior secondary school students reported low level of peer support and none $(0 \%)$ of private senior secondary school students reported high, below average and extremely low level of peer support.

In the same way in online support only $0.99 \%$ of private senior secondary school students showed above average level of online support, $89.10 \%$ of private senior secondary school students reported average level of online support and $9.90 \%$ of private senior secondary school students reported below average level of online support, the Table 9 also revealed that none $(0 \%)$ of private senior secondary school students reported extremely high, high, low and below average level of online support.

In the same way in social support only $6.98 \%$ of private senior secondary school students showed above average level of social support, $83.16 \%$ of private senior secondary school students reported average level of social support and $9.90 \%$ of private senior secondary school students reported below average level of social support, the Table 9 further revealed that $(0 \%)$ of private senior secondary school students reported extremely high, high, low and extremely low level in social support. 
Table 10: showing the difference of male and female students in their Family support

\begin{tabular}{|c|c|c|c|c|c|c|c|}
\hline SSFS & Gender & N & Mean & SD & Df & t-value & p-value \\
\hline & & & & & & \\
\hline & Male & 101 & 22.85 & 3.12 & 200 & 1.93 & .055 \\
\hline
\end{tabular}

Not significant at 0.05

It is obvious from the table 10 that mean score of female (23.68) senior secondary school students is greater than the mean score of male (22.85) senior secondary school students. The SD for male and female students is 3.12 and 23.68 the t- value is 1.93 which is not significant at 0.05 levels $(\mathrm{p}>0.05)$. So the null hypothesis stated that there exists no significant difference between male and female senior secondary school student in their family support is accepted. So it can be interpreted that female students are getting high family support as compared to male students.

Table 11: showing the difference of male and female students in their Teacher support

\begin{tabular}{|c|c|c|c|c|c|c|c|}
\hline SSTS & Gender & N & Mean & SD & Df & t-value & p-value \\
& & & & & & \\
\hline & Male & 101 & 22.63 & 4.37 & 200 & 1.57 & .117 \\
\hline & Female & 101 & 23.59 & 4.29 & & & \\
\hline
\end{tabular}

Not significant at 0.05

It is clear from the table 11 that the mean score of male and female students is 22.63 and 23.59 respectively. The SD for male and female students is 4.37 and 4.29 the t- value is 1.57 which is not significant at 0.05 levels ( $>>0.05)$. So it can be interpreted that there is no significant difference between male and female senior secondary school students in their teacher support. So the null hypothesis stated that there exists no significant difference between male and female senior secondary school student in their teacher support is accepted.

It is obvious from the table 11 that mean score of female (23.59) senior secondary school students is greater than the mean score of male (22.63) senior secondary school students. So it can be interpreted that female students are getting high teacher support as compared to male students.

Table 12: showing the difference of male and female students in their Peer support

\begin{tabular}{|c|c|c|c|c|c|c|c|}
\hline SSPS & Gender & N & Mean & SD & Df & t-value & p-value \\
\hline & Male & 101 & 20.68 & 3.17 & 200 & $3.00 . * *$ & .003 \\
\hline & Female & 101 & 22.05 & 3.28 & & & \\
\hline
\end{tabular}

Significant at $0.01 * *$

It is clear from the table 12 that the mean score of male and female students is 20.68 and 22.05 respectively. The SD for male and female students is 3.17 and 3.28 and the $t-v a l u e$ is 3.00 which is significant at 0.01 levels $(\mathrm{p}<0.05)$. So the null hypothesis stated that there exists no significant difference between male and female senior secondary school student in their peer support is not accepted. So it can be interpreted that there is significant difference between male and female senior secondary school students in their Peer support.

Further, it is obvious from the table 12 that mean score of female (20.68) senior secondary school students is greater than the mean score of male (22.05) senior secondary school students in their Peer support. So it can be interpreted that female students are getting high peer support as compared to male students.

Table 13: showing the difference of male and female students in their online support

\begin{tabular}{|c|c|c|c|c|c|c|c|}
\hline SSOS & Gender & N & Mean & SD & Df & t-value & p-value \\
\hline & Male & 101 & 21.17 & 3.47 & 200 & 1.06 & .289 \\
\hline & Female & 101 & 20.63 & 3.67 & & & \\
\hline
\end{tabular}

Not significant at 0.05

It is obvious from the table 13 that mean score of male (21.17) senior secondary school students is greater than the mean score of female (20.63) senior secondary school students. The SD for male and female students is 3.47 and 3.67 the t- value is 1.06 which is not significant at 0.05 levels $(\mathrm{p}>0.05)$. So it can be interpreted that there is no significant difference between male and female senior secondary school students in their online support. So the null hypothesis stated that there exists no significant difference between male and female senior secondary school student in their online support is accepted. 
It is clear from the table 13 that the mean score of male and female students is 21.17 and 20.63 respectively. So it can be interpreted that male students are getting high online support as compared to female students.

Table 14: showing the difference of male and female students in their Social support

\begin{tabular}{|c|c|c|c|c|c|c|c|}
\hline SST & Gender & N & Mean & SD & Df & t-value & p-value \\
\hline & Male & 101 & 79.48 & 22.35 & 200 & 0.176 & .860 \\
\hline & Female & 101 & 78.89 & 24.68 & & & \\
\hline
\end{tabular}

Not significant at 0.05

It is clear from the table 14 that the mean score of male and female students is 79.48 and 78.89 respectively. The SD for male and female students is 22.35 and 78.89 the $\mathrm{t}$ - value is 0.176 which is not significant at 0.05 level (p>0.05). So it can be interpreted that there is no significant difference between male and female senior secondary school students in their social support. So the null hypothesis stated that there exists no significant difference between male and female senior secondary school student in their social support is accepted.

Further, it is obvious from the table 14 that mean score of male (79.48) senior secondary school students is greater than the mean score of female (78.89) senior secondary school students. So it can be interpreted that male students are getting high social support as compared to female students.

Table 15: showing the difference of govt and private students in their Family support

\begin{tabular}{|c|c|c|c|c|c|c|c|}
\hline SSFS & Gender & N & Mean & SD & Df & t-value & p-value \\
\hline & Government & 102 & 23.55 & 2.76 & 200 & 1.31 & .190 \\
\hline & Private & 100 & 22.98 & 3.36 & & & \\
\hline
\end{tabular}

Not Significant at 0.05

It is clear from the table that the mean score of private and government students is 23.55 and 22.98 respectively. The SD for government and private students is 2.76 and 3.36 the $\mathrm{t}$ - value is 1.31 which is not significant at 0.05 levels ( $>00.05$ ). So the null hypothesis stated that there exists no significant difference between government and private senior secondary school student in their family support is accepted. So it can be interpreted that there is no significant difference between government and private senior secondary school students in their family support.

Further, it is obvious from the table that mean score of government (23.55) senior secondary school students is greater than the mean score of private (22.98) senior secondary school students. So it can be interpreted that government senior secondary school students are getting high family support as compared to private senior secondary school students.

Table 16: showing the difference of govt and private students in their Teacher support

\begin{tabular}{|c|c|c|c|c|c|c|c|}
\hline SSTS & Gender & N & Mean & SD & Df & t-value & p-value \\
\hline & Government & 102 & 23.60 & 4.74 & 200 & 1.60 & .110 \\
\hline & Private & 100 & 22.62 & 3.84 & & & \\
\hline
\end{tabular}

Not Significant at 0.05

It is clear from the table 16 that the mean score of government and private students is 23.60 and 22.62 respectively. The $\mathrm{SD}$ for government and private students is 4.74 and 3.84 the $\mathrm{t}-$ value is 1.60 which is not significant at 0.05 levels (p>0.05). So it can be interpreted that there is no significant difference between government and private senior secondary school students in their teacher support. So the null hypothesis stated that there exists no significant difference between government and private senior secondary school student in their teacher support is accepted.

Further, It is obvious from the table 16 that mean score of government (23.60) senior secondary school students is greater than the mean score of private (22.62) senior secondary school students. So it can be interpreted that government senior secondary school students are getting high teacher support as compared to private senior secondary school students.

Table 17: showing the difference of govt and private students in their Peer support

\begin{tabular}{|c|c|c|c|c|c|c|c|}
\hline SSPS & Gender & N & Mean & SD & Df & t-value & p-value \\
\hline & Government & 102 & 21.34 & 3.08 & 200 & 0.101 & .920 \\
\hline & Private & 100 & 21.39 & 3.51 & & & \\
\hline
\end{tabular}

Not Significant at 0.05 
It is clear from the table that the mean score of government and private students is 21.34 and 21.39 respectively. The SD for government and private students is 3.08 and 3.51 the $t-$ value is 0.101 which is not significant at 0.05 levels ( $p>0.05$ ). So the null hypothesis stated that there exists no significant difference between government and private senior secondary school student in their Peer support is accepted. So it can be interpreted that there is no significant difference between government and private senior secondary school students in their Peer support.

Further, it is obvious from the table 17 that mean score of private (21.39) senior secondary school students are greater than the mean score of government (21.34) senior secondary school students. So it can be interpreted that private senior secondary school students are getting high peer support as compared to government senior secondary school students.

Table 18: showing the difference of govt and private students in their online support

\begin{tabular}{|c|c|c|c|c|c|c|c|}
\hline SS0S & Gender & N & Mean & SD & Df & t-value & p-value \\
\hline & & & & & & \\
\hline & Government & 102 & 21.68 & 3.32 & 200 & $3.18^{* *}$ & .002 \\
\hline & Private & 100 & 20.11 & 3.66 & & & \\
\hline
\end{tabular}

\section{Significant at $0.01 * *$}

It is clear from the table 18 that the mean score of government and private students is 21.68 and 20.11 respectively. The SD for government and private students is 3.32 and 3.66 the $t-$ value is 3.18 which is significant at 0.01 levels ( $<<0.05$ ). So the null hypothesis stated that there exists no significant difference between government and private senior secondary school student in their online support is not accepted. So it can be interpreted that there exist significant difference between government and private senior secondary school students in their online support.

Further, it is evident from the table 18 that the mean score of government (21.68) senior secondary school students is greater than the mean score of private (20.11) senior secondary school students. So it can be interpreted that government senior secondary school students are getting high online support as compared to private senior secondary school students.

Table 19: showing the difference of govt and private students in their Social support

\begin{tabular}{|c|c|c|c|c|c|c|c|}
\hline SST & Gender & N & Mean & SD & Df & t-value & p-value \\
\cline { 1 - 5 } & Government & 102 & 78.68 & 25.74 & 200 & 0.309 & .758 \\
\hline & Private & 100 & 79.70 & 21.05 & & & \\
\hline
\end{tabular}

Not Significant at 0.05

It is clear from the table 19 that the mean score of government and private students is 76.68 and 79.70 respectively. The SD for government and private students is 25.74 and 21.05 the $t$ - value is 0.309 which is not significant at 0.05 levels ( $>0.05$ ) So it can be interpreted that there is no significant difference between government and private senior secondary school students in their Social support. So the null hypothesis stated that there exists no significant difference between government and private senior secondary school student in their Social support is accepted.

Further, It is obvious from the table that mean score of private (79.70) senior secondary school students are greater than the mean score of government (76.68) senior secondary school students. So it can be interpreted that private senior secondary school students are getting high Social support as compared to government senior secondary school students.

\section{CONCLUSION}

a) Maximum of senior secondary school students are having average level of social support. Majority of male, female, private, whereas government senior secondary school students reported average level of social support reported below average level of social support.

b) Maximum of senior secondary students are having average level of family support. Majority of male, female and private reported average level of Family support while government senior secondary school students reported below average level of Family support.

c) Maximum of senior secondary students are having average level of Teacher support. Majority of male, female and private senior secondary school students reported average level of Teacher support whereas government senior secondary school students perceived extremely high level of teacher support.

d) Maximum of senior secondary students are having average level of Peer support. Majority of male, female, government as well as private senior secondary school students reported average level of Peer support. As maximum private senior secondary school students reported low online support, parents and teachers should check what these students are viewing on internet. As the sites they might be using are not leading to support in reducing their anxiety. Further the teachers the teachers should focus on the problems of students in educational institutions and provide them solutions so that students can be able to take initiative for their overall well being.

e) Male and Female senior secondary school students do not differ significantly in their family, teacher and online support but differ significantly in their peer support. They do not differ significantly in their social support. Female are found to perceive more support from their peer as compared to male.male 


\section{REFERENCES}

[1] Heller, A. (1779). Relationship between Social Support and Psychological Stress. Journal of health and social behavior, pp.53-79.

[2] Isik, E. (2013). Perceived Social Support and Locus of Control as the Predictors of Vocational Outcome Expectations. Educational Sciences: Theory and Practice, 13(3), 1426-1430.

[3] Park, J., Kitayama, S., Karasawa, M., Curhan, K., Markus, H. R., Kawakami, N., \& Ryff, C. D. (2013). Clarifying the links between Social Support and Health: Culture, Stress, and Neuroticism Matter. Journal of Health Psychology, 18(2), 226-235.

[4] Turkpour, A., \& Turkpour, V. M. (2016). Social and Academic Support and Adaptation to College: Exploring the Relationships between Indicators' College Students. International Education Studies, 9(12), 53.

[5] Zavatkay, D. A. (2014). Social Support and Community College Student Academic Persistence. University of Hartford.

\section{Websites}

www.ijhssnet.com.

www.newcastle.edu.au 